\title{
From microbiota toward gastro-enteropancreatic neuroendocrine neoplasms: Are we on the highway to hell?
}

\author{
Giovanni Vitale ${ }^{1,2}$ (D) $\cdot$ Alessandra Dicitore ${ }^{2}$ (D) $\cdot$ Luigi Barrea $^{3}$ (D) $\cdot$ Emilia Sbardella $^{4}$ (D) $\cdot$ Paola Razzore $^{5}$ (D) . \\ Severo Campione ${ }^{6}$ (D) Antongiulio Faggiano ${ }^{4}$ (D) Annamaria Colao $^{3}$ (D) on behalf of NIKE $\cdot$ Manuela Albertelli . \\ Barbara Altieri • Filomena Bottiglieri • Federica De Cicco • Sergio Di Molfetta • Giuseppe Fanciulli • Tiziana Feola • \\ Diego Ferone • Francesco Ferraù • Marco Gallo • Elisa Giannetta • Federica Grillo • Erika Grossrubatscher • \\ Elia Guadagno • Valentina Guarnotta - Andrea M. Isidori • Andrea Lania • Andrea Lenzi • Fabio Lo Calzo • \\ Pasquale Malandrino - Erika Messina - Roberta Modica • Giovanna Muscogiuri • Luca Pes • Genoveffa Pizza • \\ Riccardo Pofi • Giulia Puliani • Carmen Rainone - Laura Rizza • Manila Rubino • Rosa Maria Ruggieri • Franz Sesti • \\ Mary Anna Venneri • Maria Chiara Zatelli
}

Accepted: 4 September 2020 / Published online: 15 September 2020

(C) The Author(s) 2020

\begin{abstract}
Gut microbiota is represented by different microorganisms that colonize the intestinal tract, mostly the large intestine, such as bacteria, fungi, archaea and viruses. The gut microbial balance has a key role in several functions. It modulates the host's metabolism, maintains the gut barrier integrity, participates in the xenobiotics and drug metabolism, and acts as protection against gastro-intestinal pathogens through the host's immune system modulation. The impaired gut microbiota, called dysbiosis, may be the result of an imbalance in this equilibrium and is linked with different diseases, including cancer. While most of the studies have focused on the association between microbiota and gastrointestinal adenocarcinomas, very little is known about gastroenteropancreatic (GEP) neuroendocrine neoplasms (NENs). In this review, we provide an overview concerning the complex interplay between gut microbiota and GEP NENs, focusing on the potential role in tumorigenesis and progression in these tumors.
\end{abstract}

Keywords Neuroendocrine tumors · Microbiota · Inflammation · Tumor microenvironment $\cdot$ Cytokines

Abbreviations

$\mathrm{A}-\mathrm{CAG}$

Type A chronic

atrophic gastritis

Giovanni Vitale

giovanni.vitale@unimi.it

1 Istituto Auxologico Italiano IRCCS, Laboratory of Geriatric and Oncologic Neuroendocrinology Research, Cusano Milanino, MI, Italy

2 Department of Clinical Sciences and Community Health (DISCCO), University of Milan, Milan, Italy

3 Department of Clinical Medicine and Surgery, University of Naples Federico II, Naples, Italy

4 Department of Experimental Medicine, Sapienza University of Rome, Rome, Italy

5 Endocrinology Unit, A.O. Ordine Mauriziano, Turin, Italy

6 Pathology Department, Cardarelli Hospital, Naples, Italy

\begin{tabular}{|c|c|}
\hline ATM & Ataxia-Telangiectasia \\
\hline CagA & $\begin{array}{l}\text { Cytotoxin-associated } \\
\text { gene A protein }\end{array}$ \\
\hline $\mathrm{CD}$ & Crohn's disease \\
\hline CDK & Cyclin-dependent kinase \\
\hline CDX & Homeobox protein CDX-2 \\
\hline c-MET & Tyrosine-protein kinase Met \\
\hline $\mathrm{COX}$ & Cyclooxygenase \\
\hline Cyc & Cyclin \\
\hline DLL & Delta-like ligand \\
\hline ECL & Enterochromaffin-like \\
\hline EGFR & $\begin{array}{l}\text { Epidermal growth factor } \\
\text { receptor }\end{array}$ \\
\hline ERK & $\begin{array}{l}\text { Extracellular signal-regulated } \\
\text { kinases }\end{array}$ \\
\hline $\mathrm{F}$ & Factors released by HP \\
\hline FOXO & Forkhead box O \\
\hline FZD7 & Frizzled-7 \\
\hline
\end{tabular}




\begin{tabular}{|c|c|}
\hline GEP & Gastroenteropancreatic \\
\hline GF & Growth factor \\
\hline gp30 & G protein-coupled receptor 30 \\
\hline GSK3 & Glycogen Synthase Kinase 3 \\
\hline $\mathrm{HP}$ & Helicobacter pylori \\
\hline IBD & Inflammatory bowel disease \\
\hline IL-6 & Interleukin-6 \\
\hline MEK & $\begin{array}{l}\text { Mitogen-activated protein } \\
\text { kinase kinase }\end{array}$ \\
\hline mTORC-1 & $\begin{array}{l}\text { Mammalian target of } \\
\text { rapamycin complex } 1\end{array}$ \\
\hline NBS1/NBN & Nibrin \\
\hline NENs & Neuroendocrine neoplasms \\
\hline $\mathrm{NICD} / \mathrm{CSL}$ & $\begin{array}{l}\text { Notch intracellular domain/ } \\
\text { CBF1 Suppressor of } \\
\text { Hairless Lag1 }\end{array}$ \\
\hline Notch & $\begin{array}{l}\text { Neurogenic locus notch } \\
\text { homolog protein }\end{array}$ \\
\hline OipA & Outer inflammatory protein A \\
\hline PI3k & Phosphatidylinositol-3-Kinase \\
\hline PTEN & $\begin{array}{l}\text { Phosphatase and } \\
\text { tensin homolog }\end{array}$ \\
\hline RAF & $\begin{array}{l}\text { Rapidly Accelerated } \\
\text { Fibrosarcoma }\end{array}$ \\
\hline RAS & Rat Sarcoma \\
\hline $\mathrm{Rb}$ & Retinoblastoma protein \\
\hline RNS & Reactive Nitrogen Species \\
\hline ROS & Reactive oxygen species \\
\hline RTKs & Receptor tyrosine kinases \\
\hline RUNX3 & $\begin{array}{l}\text { Runt-related transcription } \\
\text { factor } 3\end{array}$ \\
\hline SHP2 & $\begin{array}{l}\text { Src homology region } \\
2(\mathrm{SH} 2) \text {-containing } \\
\text { protein tyrosine phosphatase } 2\end{array}$ \\
\hline SMAD & $\begin{array}{l}\text { Small Mother Against } \\
\text { Decapentaplegic }\end{array}$ \\
\hline STAT & $\begin{array}{l}\text { Signal Transducer and } \\
\text { Activator of Transcription }\end{array}$ \\
\hline TFF1 & Trefoil Factor 1 \\
\hline TGF- $\beta$ & $\begin{array}{l}\text { Transforming growth } \\
\text { factor-beta }\end{array}$ \\
\hline TGFR & $\begin{array}{l}\text { Trasforming Growth } \\
\text { Factor Receptor }\end{array}$ \\
\hline TIVSS & Type IV secretion system \\
\hline TSC2 & Tuberous Sclerosis Complex 2 \\
\hline VacA & Vacuolating cytotoxin A \\
\hline VEGFR & $\begin{array}{l}\text { Vascular Endothelial } \\
\text { Growth Factor Receptor }\end{array}$ \\
\hline WNT & $\begin{array}{l}\text { Wingless-related } \\
\text { integration site }\end{array}$ \\
\hline
\end{tabular}

\section{Introduction}

In the recent years, several studies have reported the central role of gut microbiota as key determinants of numerous pathologic conditions, including cancer [1-5]. Gut microbiota is represented by different microorganisms that colonize the intestinal tract, mostly the large intestine, such as bacteria, fungi, archaea and viruses [6]. In particular, Firmicutes and Bacteroidetes phyla are the highly represented ones [7]. Several bacterial species are involved in carcinogenesis. Elevated levels of DNA of Fusobacterium nucleatum have been detected in tumor cells of colorectal adenoma and cancer $[8,9]$. In contrast, probiotic bacterium species, including Bifidobacterium and Lactobacillus genera, may exert a protective impact against cancer [10].

The gut microbial balance has a key role in several functions. Indeed, it modulates the host's metabolism, maintains the gut barrier integrity, participates in the xenobiotics and drug metabolism, and acts as protection against gastrointestinal pathogens through the host's immune system modulation [11-13]. The impaired gut microbiota, called dysbiosis, may be the result of an imbalance in this equilibrium and is linked with the development of tumors [5, 14]. Gut microbiota can interact with the tumor microenvironment, influencing the tumor growth and progression $[15,16]$. On the contrary, gut microbiota can act in the detoxification of dietary components and reduction of chronic inflammation [17]. Through this complex crosstalk the gut microbiota, depending on its own composition, may affect the cancer genesis and development, either in a positive or in a negative way. In this context, the gut microbiota can contribute to carcinogenesis through alteration of the balance of host cell proliferation and death (Figs. 1 and 2), and the modulation of immune system function (Fig. 3) [17].

Gut microorganisms can alter the resistance to cell death and proliferative signalling of host cells, by affecting genomic stability, damaging the DNA, and indirectly through a change in indigenous microbiota $[18,19]$. These mechanisms can contribute to carcinogenesis through the increase in mutational events (Fig. 1). An example is provided by colibactin, a molecule expressed by Escherichia coli [20] and Enterobacteriaceae [21], associated with colorectal carcinogenesis $[22,23]$. This molecule causes DNA damage and mutations directly or via production of high levels of reactive oxygen species [18, 24]. Similarly, in colonic epithelial cells, the Bacteroides fragilis toxin, through the over production of reactive oxygen and nitrogen species, causes indirectly DNA damage, leading to cell death or cancer-enabling mutations (Fig. 1) $[9,24]$. 
Fig. 1 Gut microorganisms can alter the resistance to cell death, and proliferative signalling, by affecting genomic stability, damaging the DNA, and through a microbial competition with others microorganisms. These mechanisms can contribute to carcinogenesis through the increase in mutational events

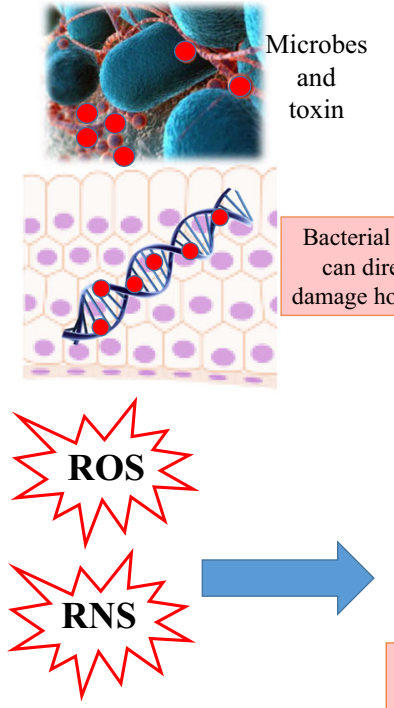

\section{Damage of the DNA}

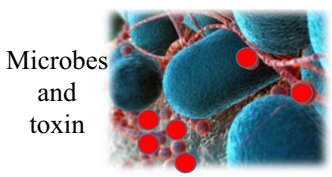

Several microorganisms have proteins that engage host pathways involved in carcinogenesis, such as $\mathrm{Wnt} / \beta$-catenin pathway (Fig. 2) [25]. The Wnt/ $\beta$-catenin pathway regulates different cell behaviours [26, 27], such as axis formation during development [28], maintenance of stem cell in adulthood [29], and in tissue regeneration [30]. In the gastrointestinal tract the Wnt pathway maintains the self-renewal capacity of epithelial stem cells and aberrant activation of this pathway may lead to cancer [31]. Therefore, the barrier maintenance between host and microbe represents a critical point in the development of some tumors [32-39].
When the barriers are breached, microbes can act on immune responses leading to activation pro-inflammatory or immunosuppressive pathway (Fig. 3). Interestingly, the microbial dysbiosis may contribute to both cancer pathogenesis and progression $[13,40]$. In fact, several inflammatory factors such as pro-inflammatory cytokines and chemokines, reactive oxygen and nitrogen species, are associated to growth and spread of the cancer (Fig. 3). Recognition of microbial components, through Toll-like receptors, can activate downstream signalling pathways, such as NF-kB, which leads to the production of proinflammatory factors (Fig. 3) [41]. In addition,
Fig. 2 An important target of cancer-associated microbes is the $\beta$-catenin signalling. The microbes bind E-cadherin on colonic epithelial cells within a disrupted barrier, and trigger $\beta$-catenin activation, resulting in dysregulated cell growth

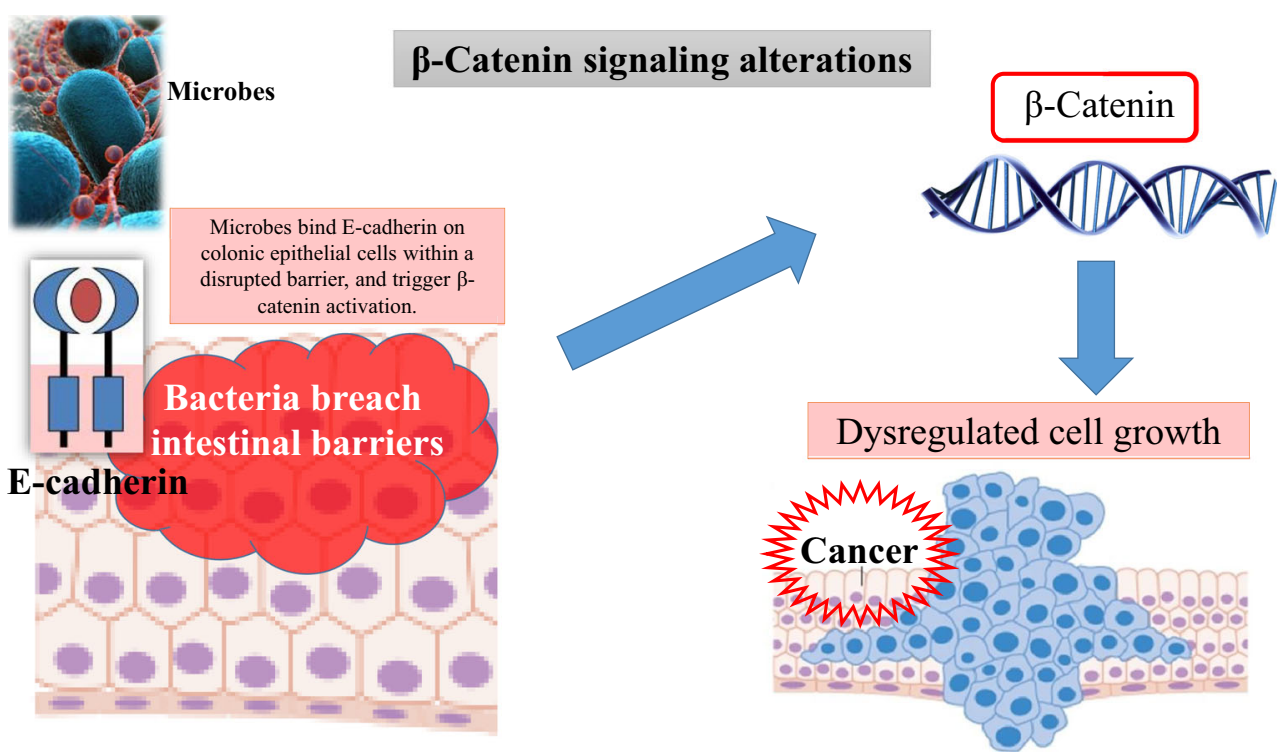


Fig. 3 The loss of boundaries between host and microbe and the activation of chronic inflammation via NF-kB and STAT3 signalling promote carcinogenesis

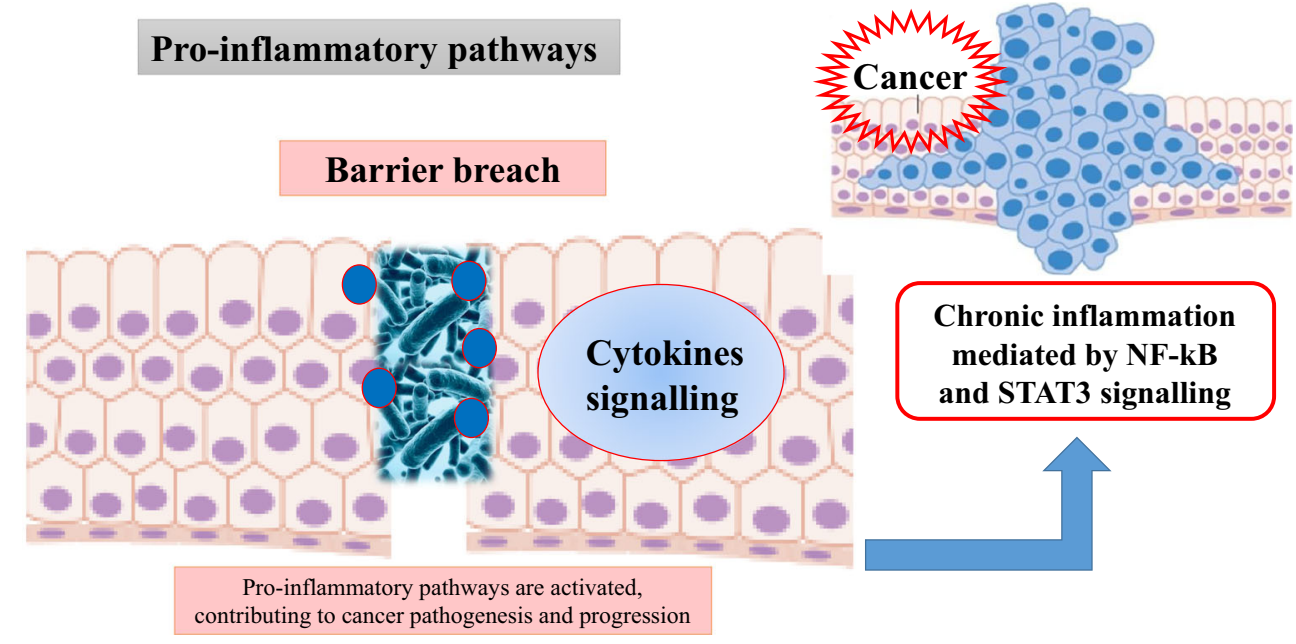

the activation of innate immune system due to the breached of gut barriers, leads to adaptive immune responses modulated by several cytokines and STAT3 activation, all associated to cancer progression (Fig. 3) [42-48].

While most of the studies have focused on the association between microbiota and gastrointestinal adenocarcinomas, very little is known about gastroenteropancreatic (GEP) neuroendocrine neoplasms (NENs). In this review, we provide an overview concerning the complex interplay between gut microbiota and GEP NENs, focusing on the potential role in tumorigenesis and progression of these tumors.

\section{Helicobacter pylori (HP) and NENs: Preclinical and clinical studies}

HP is a gram-negative bacterium that infects human beings colonizing gastric mucosa and thus eliciting chronic gastritis [49]. This process can progress within years and decades to chronic atrophic gastritis, that is characterized by a loss of appropriate glands, either in form of lamina propria fibrosis or glandular metaplasia. This condition appears to be a major cause of gastric adenocarcinoma [50-53]. In 1994 the World Health Organization and International Agency for Research on Cancer consensus group reported that epidemiologic and histologic evidences were sufficient to consider HP as a definite carcinogen $[54,55]$. Gastric precancerous cascade is determined by both inflammatory process and DNA damage in cells infected by HP (Fig. 1).

Gastric NENs, also defined gastric carcinoids, are rare tumors of the stomach that arise from the enterochromaffin-like (ECL) cells [56]. Several evidences suggested a potential carcinogenic role for HP in NENs.

There are three types of gastric NENs, classified according to their histology and malignant potential. A majority are defined as type $I$ that are associated to chronic atrophic gastritis, either autoimmune-driven or as a consequence of HP infection, and type II, associated to gastrinoma in patients with Multiple Endocrine Neoplasia Syndromes type 1 syndrome. These first two types are tumors that develop secondary to high gastrin levels. The majority of types I and II gastric carcinoids are small $(1-2 \mathrm{~cm})$, multiple, and mainly confined to the gastric mucosa/submucosa layers. These lesions generally have an indolent course associated with low metastatic potential. On the contrary, type III gastric carcinoids are solitary and large $(>2 \mathrm{~cm})$ tumors, with no known correlation to gastrin production, that infiltrate the muscular layers and are related with the development of local and distant metastases [57, 58].

A longstanding HP infection was shown to be associated with chronic atrophic gastritis [59] and abnormalities in the gastric secretion. Chronic gastritis due to HP has been considered as a risk factor for the development of gastric adenocarcinoma [59]. However, few studies showed that HP infection induces formation of carcinoids of the stomach in animals and humans [58, 60, 61].

In 1999 Hirayama and Colleagues [60] showed that longterm colonization by HP is a crucial risk factor for the development of gastric adenocarcinoma and carcinoid in a Mongolian gerbil model. Kagawa et al. followed the histological changes of HP-infected stomachs of Mongolian gerbils compared to uninfected animals for 24 months and reported that HP infection can cause ECL-like cell tumors due to hypergastrinemia [62]. Interestingly, HP eradication prevented the occurrence of gastric carcinoid in the Mongolian gerbil stomach [63].

In humans, a population-based case-control study, comparing 1,138,390 cancer cases with 100,000 matched individuals without cancer, showed that subjects with chronic atrophic gastritis and pernicious anemia have a significantly increased risk of type I gastric carcinoids (odds ratio, 11.43; 95\% CI 8.90-14.69) [64].

Solcia et al. showed a series of 60 gastric endocrine tumors, comprising 44 body-fundus argyrophil carcinoids, of which 23 developed in a background of hypergastrinemia and type A 
chronic atrophic gastritis (A-CAG), especially characterized with histologic patterns of an autoimmune process. Only $22 \%$ of 36 carcinoids and $21 \%$ of 19 A-CAG carcinoids had HP colonization, compared to $50 \%$ of 14 A-CAG-associated neuroendocrine carcinomas or mixed endocrine-exocrine tumors. On the other hand, $84 \%$ of 150 patients with early gastric cancer ( $p<0.001$ versus carcinoids), mostly with A-CAG, had HP colonization [65]. They concluded that high gastrin levels and local mechanisms activated by chronic autoimmune gastritis are some of the factors that contribute in the pathogenesis of relatively indolent A-CAG-associated carcinoids, while active end-stage HP gastritis associated to environmental factors could contribute to more severe epithelial transformation, leading to gastric cancer and to neuroendocrine carcinomas or mixed endocrine-exocrine tumors [65]. In addition, most patients with A-CAG, despite having a low incidence of current overt infection, have been previously infected with HP, as demonstrated by the presence of HP antibodies [66].

In a recent study from an Indian NEN Center, gastric carcinoids constituted about $32 \%$ of all GEP NENs. At the histopathological review, a high incidence of multifocal atrophy in the antrum, fundus and body was observed, while in autoimmune gastritis, atrophy is especially localized to the gastric body [67]. The authors have speculated that in India, where HP infection is very common, multifocal atrophic gastritis caused by HP can represent a crucial risk factor in the development of gastric NENs.

\section{Effects of HP colonization on signalling pathways involved in NEN transformation}

Although further epidemiological studies are necessary to confirm the association between HP infection and the development of gastric NENs, there are several conceptual evidences of mechanisms involved in these events.

It is clear that HP infection induces the development of inflammatory disorders. Atrophic gastritis and ECL hyperplasia are the final consequence of this inflammatory process (Fig. 4). The destruction of the gastric parietal cells reduces the production of hydrochloric acid, promoting hypergastrinemia. The gastrin excess stimulates not only histamine secretion but also ECL cells proliferation, via the gastrin/ cholecystokinin-B receptor [68]. This process, along with dysplastic lesions, ultimately may lead to the development of NENs [69]. In addition, HP facilitates gastric ECL cell proliferation by other mechanisms. The mucosal inflammation, induced by HP, has been shown to cause excessive apoptosis, which in turn leads to proliferation. Lipopolysaccharides also appear to influence tumor ECL cell proliferation [70]. In rats HP lipopolysaccharides stimulate histamine release via the CD14 receptor. Histamine is a potent mitogenic factor, able to potentiate gastrin-driven DNA synthesis in ECL cells [71]. Another factor involved in ECL cell proliferation is REG protein, a growth factor, which may be stimulated by HP infection [72].

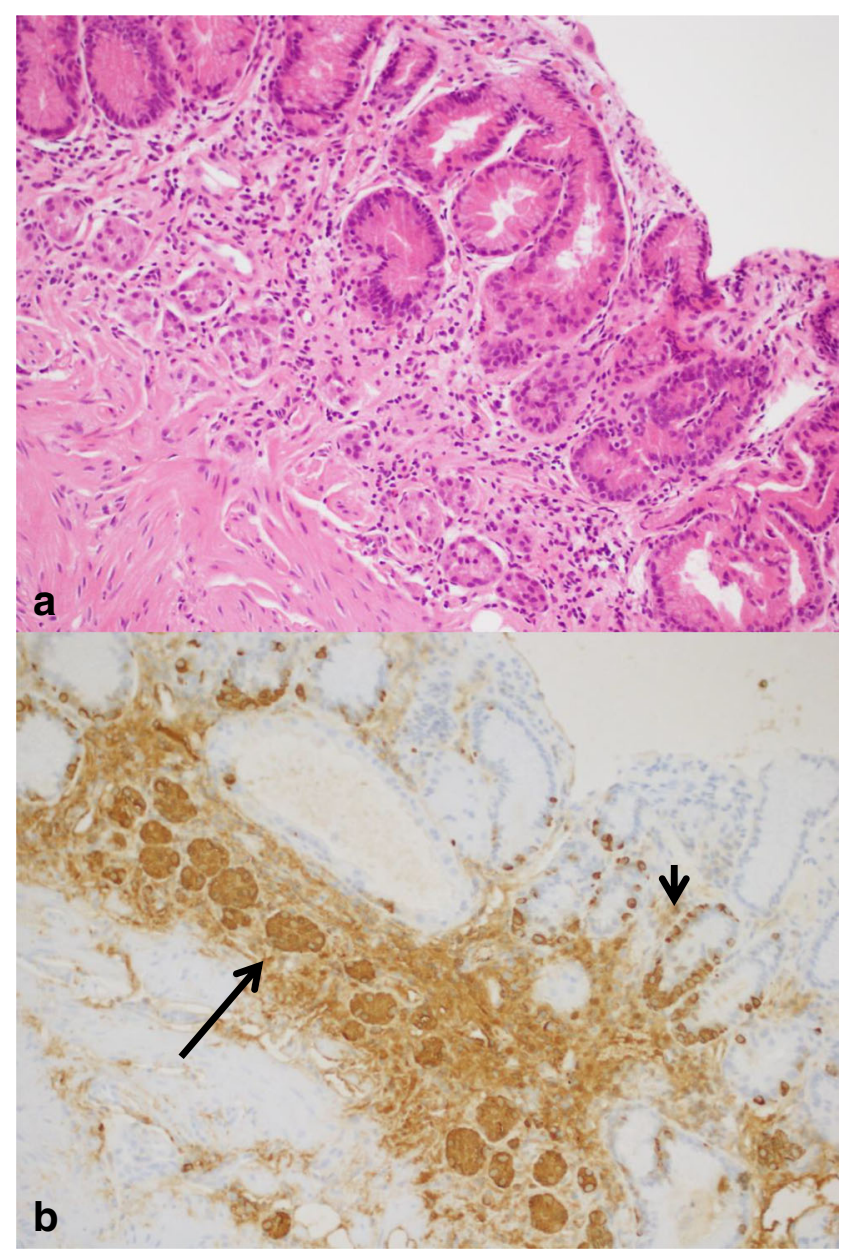

Fig. 4 Helicobacter pylori-associated atrophic gastritis. A complete loss of oxyntic glands is evident (a) (haematoxylin eosin, 200x magnification) with a linear (short arrow) and nodular (long arrow) ECL cell neuroendocrine hyperplasia (b) (immunohistochemistry Chromogranin A, 200x magnification, in an adjacent section of A)

In the last years, several molecular pathways have emerged to explain how HP evades host defences, damages gastric tissue and promote tumorigenesis. Three major virulence factors appear to have a role in gastric tumorigenesis: vacuolating cytotoxin A, type IV secretion system, and cytotoxinassociated gene A protein [73]. Although most studies have focused on gastric adenocarcinoma and epithelial cells, in this section we will discuss the intracellular signalling pathways able to disrupt normal physiology of gastrointestinal mucosal cells during HP infection and are in common with the development of GEP NENs (Fig. 5). For most of these HPperturbated signalling pathways, we cannot exclude a direct involvement also in ECL cells.

\subsection{Tyrosine kinase-mediated signalling}

Receptor tyrosine kinases belong to a family of receptors that mediate cellular responses to extracellular signals such as growth factors, hormones and cytokines. These receptors play 


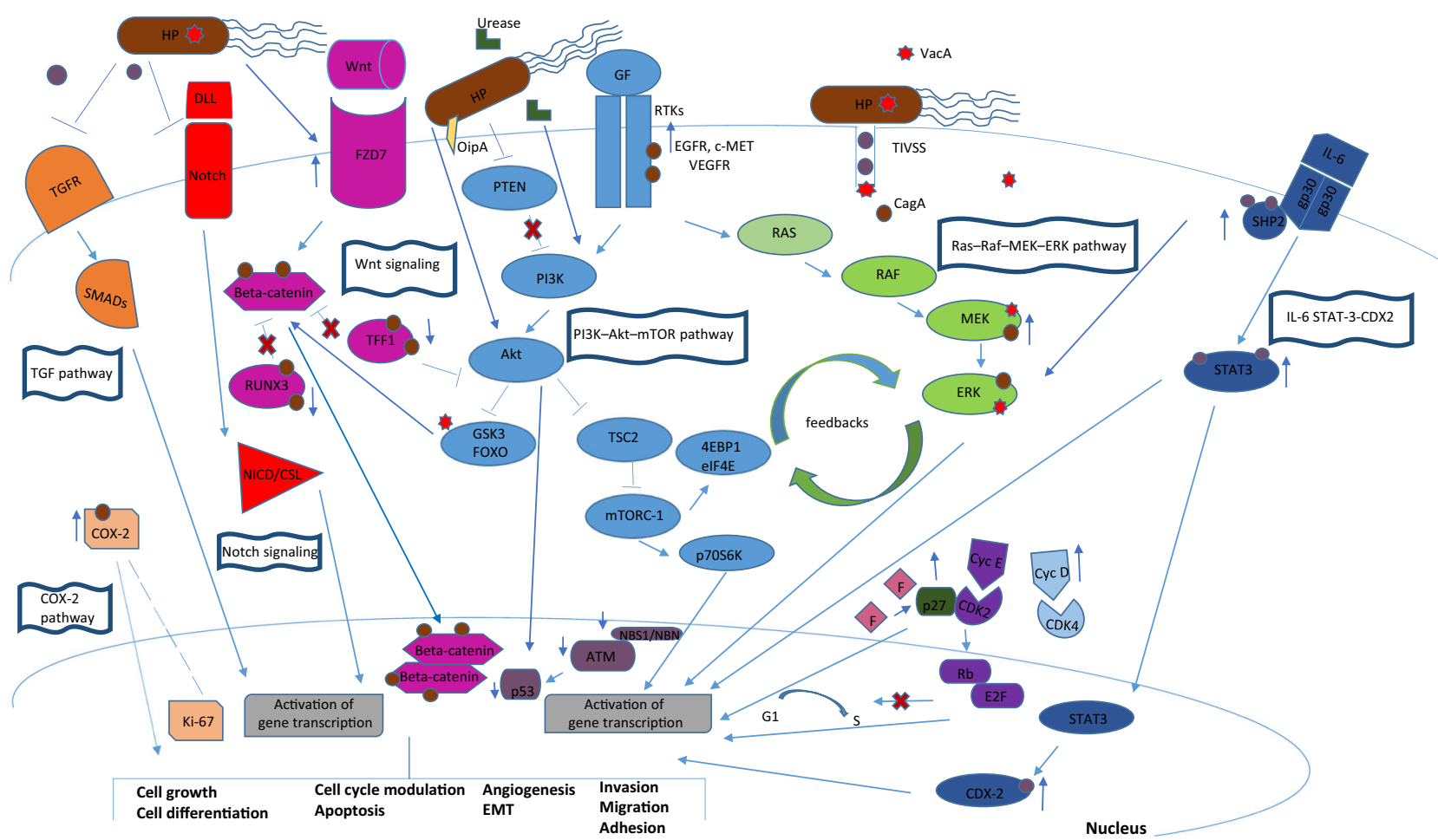

Fig. 5 Common cellular signalling pathways involved in GEP NENs and perturbated after HP colonization

an important role in cell proliferation, survival and differentiation. Several receptor tyrosine kinases are frequently upregulated in GEP NENs, such as the receptor families for vascular endothelial growth factor, epidermal growth factor and tyrosine-protein kinase c-Met [74-77]. Receptor tyrosine kinases activity results in the activation of several transduction systems, including the canonical Ras signalling pathway and PI3K-Akt-mTOR [78].

HP stimulated vascular endothelial growth factor receptor expression in human microvascular endothelial cells (HMEC1) [79] and epidermal growth factor receptor expression in gastric epithelial cells [80]. HP strains carrying the type IV secretion system induce gastrin promoter activity via epidermal growth factor receptor [81]. Epidermal growth factor receptor is also activated by HP-integrin- $\beta 1$ interaction [82]. HP infection may activate c-Met expression through cytotoxinassociated gene A protein in gastric epithelial cells, resulting in ERK1, 2 activation [83].

\subsection{RAS-RAF-MEK-ERK pathway}

The RAS-RAF-MEK-ERK pathway, activated by several growth factors, is involved in cell growth and cell differentiation. Dysregulation of this crucial pathway occurs due to overexpression and/or overactivation of the $R A S$ and $R A F$ genes [84]. Mutations of $R A S$ [85-87] are very rare events in GEP NENs, with reported mutation frequencies [87] of HRAS $1 \%$ (2/150), KRAS $8 \%$ (10/125), NRAS $0.7 \%$ (2/274) or BRAF $1 \%(4 / 369)$. Although activating mutations of $B R A F$ are rare in GEP NENs [88], wildtype $B R A F$ and its activating small $G$ protein, $R A P-1$, are highly prevalent in the majority of GEP NENs. Overexpression of $R A P-1$ is able to activate MAPKsignalling and the expression of mitogenic transcription factors of GEP NEN cells [89]. Some authors have reported that RAF-1 signalling cascade activation is associated with the modulation of neuroendocrine phenotype in BON-1 cells, a well-known neuroendocrine tumor cell line [90, 91].

Gastrin, via the cholecystokinin 2 receptor, is the principal regulator of ECL cell proliferation via a MAPK-activated signal transduction cascade [92] and induction of the activator protein-1 complex transcription factor [93]. The latter regulate several genes involved in cell cycle progression (eg, cyclin genes) [94]. ECL cell proliferation is associated with fos/jun transcription activation by the MAPK pathway after gastrinmediated RAS activation [95].

HP rapidly activates MAPKs upon contact with gastric epithelial cells [96] and, indirectly, promotes gastrin-induced MAPK transduction pathways in ECL cells through histamine release [95]. Several bacterial factors are involved in MAPK activation, including the vacuolating cytotoxin A $[97,98]$ and cytotoxin-associated gene A protein [99]. However, the type IV secretion system appears to be crucial for complete phosphorylation of ERK and MAPK [96, 100].

\subsection{PI3K-AKT-mTOR pathway}

The PI3K-AKT-mTOR pathway plays a relevant role in the pathogenesis and progression of GEP NENs [101]. AKT is the 
major kinase, which regulates cell survival and proliferation by inhibiting proapoptotic mitochondrial proteins and cellcycle modulators. Dysregulation of this pathway is due to activation of PI3K or loss-of-function mutation of PTEN, $T S C 2$ and GSK3. Studies in small bowel NEN cell lines revealed a stronger activation of PI3K/AKT/mTOR pathway compared to that observed in normal ECL cells [102].

In gastric epithelial cells HP infection induced PTEN phosphorylation, which activated AKT [103] and inhibited apoptosis [104]. Interestingly, the HP urease seems to have a relevant role in the activation of the PI3K-AKT-mTOR pathway in gastric cells [105].

\subsection{Notch signalling}

Notch signalling pathway plays an important role in maintaining a dynamic balance between cell proliferation, differentiation and apoptosis and is an essential signalling in the regulation of inflammatory and immune responses. Notch signalling can have an oncogenic or tumour suppressor role. Histopathological studies have shown that Notch-1 is absent or poorly expressed in well-differentiated GEP NENs, suggesting a possible role as a tumour suppressor gene in these tumors [106].

After HP invasion, a significant reduction in the mRNA expression level of Notch-1 and Notch-2, together with low levels of active forms of Notch-1 and Notch-2, have been observed in GES-1, a human gastric epithelial cell line [107].

\subsection{Wnt/ß-catenin pathway}

$\mathrm{Wnt} / \beta$-catenin pathway is crucial to embryo development and adult tissue homeostasis. Aberrant activation of this pathway can cause uncontrolled cell growth and malignant transformation (Fig. 2). In NENs, cytoplasmic and nuclear beta-catenin accumulation, suggestive of $\mathrm{Wnt} / \beta$-catenin signalling activation, has been reported in 1/12 gastro-intestinal NENs and 1/6 bronchial carcinoids [108]. Sun and colleagues found cytoplasmic accumulation and/or nuclear translocation of $\beta$ catenin in about $30 \%$ of gastro-intestinal NENs $(27 / 80)$ [109]. In 72 cases of gastrointestinal NENs, accumulation of $\beta$-catenin in the cytoplasm and/or nucleus has been observed in $79 \%$ of cases (57/72) and mutations in exon 3 of $\beta$-catenin in $37 \%$ of tumors [110]. APC gene is a negative regulator that controls $\beta$-catenin concentrations and modulates cell adhesion. In ileal NENs, the APC gene was deleted in $15 \%$ $(4 / 27)$ and somatic mutations of this gene were detected in $23 \%$ (7/30) of examined tumour samples, including 57\% missense and $14 \%$ nonsense/frameshift mutations [111].

HP activates $\mathrm{Wnt} / \beta$-catenin signalling through several mechanisms in gastric cells. Cytotoxin-associated gene A protein induces nuclear $\beta$-catenin accumulation in vivo and in vitro $[112,113]$ and activates the $\beta$-catenin through an independent phosphorylation manner in human gastric cancer epithelial cell lines or in rodent gastric cells [114]. The vacuolating cytotoxin $\mathrm{A}$ induces $\mathrm{Wnt} / \beta$-catenin signalling through the activation of PI3K/AKT pathway [115]. HP can also activate $\mathrm{Wnt} / \beta$-catenin pathway by recruiting tumorassociated macrophages [116]. Wnt $/ \beta$-catenin activation in HP infection has been linked to angiogenesis in the gastric mucosa, which is an important process for tumorigenesis [117].

\subsection{The transforming growth factor-beta (TGF- $\beta$ ) signalling}

The TGF- $\beta$ exists in at least three isoforms: TGF- $\beta 1$, TGF- $\beta 2$, and TGF- $\beta 3$ [118]. TGF- $\beta$ signalling is mediated by TGF- $\beta$ receptors 1 and 2 and intracellular SMAD proteins. These factors are involved in cell cycle regulation, apoptosis, tumor angiogenesis and invasion [119-121]. A high expression level of TGF- $\beta$ receptor 1 (intensity scores 2 and 3 ) has been detected in almost 100\% of GEP NENs [122]. The tumor suppressor SMAD4 has been demonstrated to be often mutated or deleted in small intestinal NENs in approximately $45 \%$ of cases $(22 / 48)$ [123, 124].

TGF- $\beta 1$ is a potent stimulator of ECL cell proliferation through downregulation of SMAD4 and activation of the ERK1/2 pathway [125]. In vivo studies have shown that HP infection induced upregulation of TGF- $\beta 1$ in gastric mucosa. This effect is positively correlated with the vacuolating cytotoxin A genotype and the grade of chronic inflammation [126].

\subsection{TP53}

The TP53 gene encodes p53, an important tumour suppressor modulating a network of genes implicated in DNA repair, cell growth arrest or cell senescence, apoptosis and autophagy [127]. The main effectors of TP53 expression are WIP1, $M D M 2, M D M X, A T M$ and ATR genes [128, 129]. Mutations in the TP53 gene have been consistently detected in poorly differentiated GEP NENs, with a frequency ranging from $20 \%$ to $73 \%$ of cases [130] and correlate with poor survival [131]. $\mathrm{Hu}$ and co-workers [132] observed a high rate of copy number gains of MDM2 in 22\%, MDM4 in 40\% and WIP1 in 51\% of pancreatic NENs. High ATM expression in pancreatic NENs was associated with higher tumour differentiation, lower tumour size, lower recurrence rate and better prognosis [133], while loss of ATM expression was common in metastasized disease and resulted to be associated with a worse prognosis [134]. Interestingly, in the African rodent mastomys Tp53 seems to have a relevant role during the development of hypergastrinemia-induced ECLoma [135].

HP is able to inhibit the tumor suppressor TP53 through AKT activation and subsequent degradation of p53 in gastric 
epithelial cells [136]. Inhibition of p53 may provide advantages to HP and allow it to alter cellular homeostasis without triggering cell cycle arrest or apoptosis [137].

\subsection{Cyclin-dependent kinases (CDKs)}

The family of CDKs belongs to a superfamily of 20 members, which catalyse the phosphorylation of key proteins and transcription factors implicated in cell cycle transition [138-140]. Cyclin $\mathrm{C} / \mathrm{CDK} 3$, Cyclin D/CDK4 and Cyclin D/CDK6 are involved in $\mathrm{G}_{0}-\mathrm{G}_{1}$ transition and the early $\mathrm{G}_{1}$ phase by phosphorylating the tumour suppressor retinoblastoma protein and thus activating E2F [141]. These pathways are commonly altered in tumors, including GEP NENs [142, 143]. In 92 tumour samples of human pancreatic NENs, overexpression of CDK 4 and retinoblastoma protein was detected in $58 \%$ and $68 \%$, respectively. Gene amplifications of CDK4 or CDK6 were found in $19 \%(5 / 26)$ of investigated pancreatic NENs [144]. p27 is CDK inhibitor encoded by the CDKN1B gene and regulates the transition from cell cycle phase $G_{0} / G_{1}$ to $S$ and is implicated also in cellular motility and apoptosis. Frameshift mutations or deletions of $C D K N 1 B$ were reported in about $8-23 \%$ of small intestinal NENs $[145,146]$. Loss of p27 protein expression, which occurred in $21 \%$ of 327 GEP NENs, was a predictor of poor prognosis [147]. The inactivation of $R B 1$ gene, which occurs mainly by somatic mutations, has been reported in $71 \%$ of poorly differentiated pancreatic neuroendocrine carcinomas [148]. Both message and protein levels of cyclin D1 increased in vitro during ECL cell tumorigenesis $[149,150]$.

HP and related inflammatory response are associated in vivo with alterations in expression of cyclin D1 and CDKN1B and abnormalities in epithelial cell proliferation, cell cycle progression and apoptosis. HP infection can stimulate proliferation of gastric mucosal epithelial cells [151], through activating the MAPK pathway and promoting the expression of cyclin D1 [152]. In addition, HP decreases p27 expression in gastric cells through epigenetic mechanisms $[153,154]$. Interestingly, low gastric p27 may promote carcinogenesis associated with HP infection by inhibiting apoptotic pathways [155].

\subsection{Interleukin-6/STAT3/CDX2}

The interleukin-6/STAT3/CDX2 pathway represents a relevant factor for the tumor progression of gastrointestinal NENs [156-158].

It has been reported that the proinflammatory cytokine interleukin-6 is upregulated during HP infection in the gastric mucosa, with a potential involvement in gastrointestinal tumor development [159]. Interleukin- 6 binds to the $\alpha$-subunit of its specific receptor and activates two main signalling pathways: SHP-2/ERK and JAK/STAT [99], able to promote mucosal inflammation and carcinogenesis [160-163]. In addition, HP infection induces CDX2 expression in patients with chronic gastritis and intestinal metaplasia [163].

\subsection{Cyclooxygenase-2 (COX-2)}

COX-2 is able to modulate cell apoptosis and adhesion and promote tumor cell metastasis [164]. COX-2 overexpression was observed in 54\% (126 of 234) of GEP NENs and was found to be positively correlated with Ki-67 labelling index and associated with poor prognosis [165].

COX-2 is induced in HP-positive gastritis and present at high levels in gastric antrum, where bacterial density is elevated [166]. This suggested that expression of COX-2 was a direct response to HP infection [167]. In patients with HPpositive gastric mucosal lesions, positive detection rate of COX-2 resulted significantly higher than that in HP-negative gastric mucosal lesions [168].

\section{Inflammatory bowel disease (IBD), NENs and microbiota, is there a possible link?}

\subsection{IBD and NENs}

IBD is a group of inflammatory conditions of the colon and small intestine, that includes Crohn's disease (CD) and ulcerative colitis.

Data from population study and large pathological and disease registry suggest an association between IBD and intestinal NENs. Among a cohort of 20,917 patients affected by CD, 9 NENs were observed, resulting, in a 7-fold increased neoplastic risk, as compared to the general population [169]. In a prospective observational 7-year follow-up cohort study in 590 patients with mono-institutional IBD diagnosis, neuroendocrine carcinoma and rectal carcinoid occurrence was increased $(\mathrm{RR}=13.1,95 \% \mathrm{CI}: 1.82-29.7$ and $\mathrm{RR}=8.94$, 95\%CI: 1.18-59.7 respectively) [170]. Similarly, in a large retrospective study from US-based population database of electronic medical records of $62,817,650$ individuals from 26 major healthcare institutions, 4530 of them were reported to have a large colonic carcinoid diagnosis and, in several cases, a personal history of CD or ulcerative colitis. For these subjects an increased risk to develop large bowel carcinoid was observed: OR 6.93 (95\% CI 5.55-8.64, $p<0.0001)$ and OR 6.45 (95\% CI 5.24-7.95, p <0.0001), respectively [171]. Sciola et al. reported a prevalence for IBD of $4.8 \%$ in a series of 83 GEP NENs. This value was higher than that reported in general population [172]. In contrast, a recent Dutch nationwide study reported in the entire cohort of IBD patients from national pathological database 51 patients with concomitant IBD and colonic NENs with an estimated prevalence rate ratios between 2.8 and 4.1. These values were lower than ones 
from colonic resection specimens for diverticulitis and ischemia adjusted for resection type, sex and age, suggesting an incidental finding because of frequent colonic resection [173].

Detailed clinical and pathological features data for NENs in IBD is however lacking in literature. Data arose from case reports and surgical or pathological series revision with different collection data method and analysis [172, 174]. Interestingly, only a minority of patients with both diseases developed an aggressive NEN. In fact, only $8.3 \%(3 / 36)$ of NENs with IBD, reported by Derikx et al., showed distant metastasis (stage IV). In a recent retrospective study, Wong reported detailed clinical and pathological data in 17 patients with IBD and neuroendocrine proliferation. Eight patients $(47.1 \%)$ were classified as neuroendocrine cell micronests with subcentimetric lesions and no oncological strength, while in the remain $9(52.9 \%)$ a $1-11 \mathrm{~mm}$, low grade and stage I NEN was reported [175].

\subsection{Microbiota and IBD}

IBD is associated with alterations in intestinal microbiota. The pathogenesis of the disease involves complex interactions between immune system, the microbiome and environmental factors in genetically susceptible individuals [176]. Despite an impressive number of 163 genetic loci of IBD susceptibility, most of which associated with both $\mathrm{CD}$ and ulcerative colitis, other factors as environmental exposures seem to contribute to disease pathogenesis. Most evidences point to the interaction between the host mucosal immune system and microbes, both at the epithelial cell surface and within the gut lumen, as one of the most important factors [177]. In patients with IBD, a compositional change in microbiota and an expansion of potential pathogens have been reported. In particular, a depletion in specific commensal bacteria, as Lachnospiraceae (class of Clostridia and philum of Firmicutes) and Bacteroidetes phylum, and an enrichment in Proteobacteria was reported [178] in patients with IBD compared to healthy subjects. There are no reliable data if microbial composition changes in human have a causative role in inducing intestinal inflammation or if could be a side effect (following acute infection or host inflammatory responses) and no specific pathogenic microorganism was recognized as singular cause of chronic IBD [179, 180]. However, alterations in gut microbiota were found in $\mathrm{CD}$ and ulcerative colitis, with a relevant impact of aging and disease stage. In fact, a decreased amount of Roseburia hominis and Faecalibacterium prausnitzii (Fprau) has been observed using RT-PCR in ulcerative colitis fecal samples [181]. In CD a global decrease in the biodiversity of the fecal microbiota with markedly reduced diversity of Firmicutes and in particular of the Clostridium leptum phylogenetic group was reported using a metagenomic approach [182]. An elegant paper from Sokol reported lower proportion of Fprau in resected ileal mucosa from patients with CD associated with endoscopic recurrence at 6 months, suggesting a significant role for microbiota variation in recurrent disease [183]. In this study an anti-inflammatory property of Fprau has been demonstrated both in vitro and in vivo.

\subsection{Microbiota e NENs}

Although only few studies are available in literature on microbiota and NENs, there are common patterns of microbiome composition with IBD. In 2008 Dorffel showed a significant depletion of Fprau in 12/23 patients with NENs, as previously reported in CD [181, 183]. Another study evaluated microbial fecal composition using microscopic examination and fluorescence and in situ hybridization in 66 patients with NENs (25 from foregut, 30 from midgut and 11 from hindgut origin), 25 healthy subjects and 50 patients with CD. Depletion of Fprau was observed in $67 \%$ of patients with midgut NENs, $84 \%$ of untreated $\mathrm{CD}$ and $56 \%$ of treated CD, while only in $3 \%$ of patients with chronic idiopatic diarrhea and $0 \%$ of healthy controls. In the same study fecal Enterobacteriaceae were significantly increased in NENs and CD patients. The effect of NEN therapy on microbiota was also analyzed. Somatostatin analogues had no influence on the concentration of habitual or occasional bacterial groups, while interferon alpha-2b and chemotherapy induced a massively increased in Fprau. Similar data were reported in successfully treated CD patients despite different drugs were used [184].

Therefore, a depletion of Fprau has been reported both in patients with IBD and NENs. A possible protective effect of Fprau on IBD inflammation has been proposed. Fprau is known to have a role in producing a large amount of butyrate, able to modulate the immune system and to protect the gut barrier integrity. The gut microbiota-derived butyrate, not also supplies energy source for intestinal epithelial cells, but also inhibits inflammation through epigenetic mechanisms [185]. In addition, recent data suggested a protective effect of Fprau for several tumors, such as colon carcinoma [186], breast cancer [187] and melanoma [188].

\section{Conclusions}

In the last years there is mounting evidence supporting the role of the gut microbiome in the pathogenesis of several tumors and response to the therapy.

While HP appears to be involved in the development of gastric NENs, no clear data are currently available concerning the effect of microbiota on the development of other GEP 
NENs. Preliminary data reported a depletion of Fprau in patients with midgut NENs and in subjects with IBD. However, no cause-effect relationship between these events has been conclusively demonstrated.

In addition, a potential role for gut dysbiosis was reported in IBD not only for bacteria species but also for fungal microbiota (mycobiota) and viral microbiota (virobiota) $[189,190]$. While, no data for mycobiota or virobiota modifications are available in NENs [191].

Further studies are required to clarify the potential role of the intestinal microbiota (including bacteria, fungi and viruses) in the development and progression of GEP NENs. These aspects could have relevant clinical implications in the prevention and therapy of these tumors.

Acknowledgements This review is part of the 'Neuroendocrine Tumors Innovation Knowledge and Education' project led by Prof. Annamaria Colao and Prof. Antongiulio Faggiano, which aims at increasing the knowledge on neuroendocrine tumors.

We would like to acknowledge all the Collaborators of the "NIKE" project:

Manuela Albertelli - Genova; Barbara Altieri - Wurzburg; Filomena Bottiglieri - Napoli; Federica De Cicco - Napoli; Sergio Di Molfetta Bari; Giuseppe Fanciulli - Sassari; Tiziana Feola - Roma; Diego Ferone Genova; Francesco Ferraù - Messina; Marco Gallo - Torino; Elisa Giannetta - Roma; Federica Grillo - Genova; Erika Grossrubatscher Milano; Elia Guadagno - Napoli; Valentina Guarnotta - Palermo; Andrea M. Isidori - Roma; Andrea Lania - Milano; Andrea Lenzi Roma; Fabio Lo Calzo - Avellino; Pasquale Malandrino - Catania; Erika Messina - Messina; Roberta Modica - Napoli; Giovanna Muscogiuri - Napoli; Luca Pes - Sassari; Genoveffa Pizza - Avellino; Riccardo Pofi - Roma; Giulia Puliani - Roma; Carmen Rainone Napoli; Laura Rizza -Roma; Manila Rubino - Milano; Rosa Maria Ruggieri - Messina; Franz Sesti - Roma; Mary Anna Venneri - Roma; Maria Chiara Zatelli - Ferrara.

Funding Open access funding provided by Università degli Studi di Milano within the CRUI-CARE Agreement. This work was supported by the Italian Ministry of Education, University and Research (MIUR): PRIN 2017Z3N3YC.

\section{Compliance with ethical standards}

Conflict of interest A. Colao has received consultant fees from Novartis and Ipsen. A. Faggiano has received consultant fee from Triple AAA and Ipsen. G. Vitale has received consultant fees from Novartis.

Open Access This article is licensed under a Creative Commons Attribution 4.0 International License, which permits use, sharing, adaptation, distribution and reproduction in any medium or format, as long as you give appropriate credit to the original author(s) and the source, provide a link to the Creative Commons licence, and indicate if changes were made. The images or other third party material in this article are included in the article's Creative Commons licence, unless indicated otherwise in a credit line to the material. If material is not included in the article's Creative Commons licence and your intended use is not permitted by statutory regulation or exceeds the permitted use, you will need to obtain permission directly from the copyright holder. To view a copy of this licence, visit http://creativecommons.org/licenses/by/4.0/.

\section{References}

1. Muscogiuri G, Balercia G, Barrea L, Cignarelli A, Giorgino F, Holst JJ, et al. Gut: a key player in the pathogenesis of type 2 diabetes? Crit Rev Food Sci Nutr. 2018;24:1294-309.

2. Barrea L, Muscogiuri G, Annunziata G, Laudisio D, Pugliese G, Salzano C, et al. From gut microbiota dysfunction to obesity: could short-chain fatty acids stop this dangerous course? Hormones (Athens). 2019;18:245-50.

3. Zhang YL, Li S, Gan RY, Zhou T, Xu DP, Li HB. Impacts of gut bacteria on human health and diseases. Int J Mol Sci. 2015;4: 7493-519.

4. Feng Q, Chen WD, Wang YD. Gut microbiota: an integral moderator in health and disease. Front Microbiol. 2018;9:151.

5. Kong F, Cai Y. Study insights into gastrointestinal cancer through the gut microbiota. Biomed Res Int. 2019;3:1-8.

6. Lynch SV, Pedersen O. The human intestinal microbiome in health and disease. N Engl J Med. 2016;375:2369-79.

7. Greenhalgh K, Meyer KM, Aagaard KM, Wilmes P. The human gut microbiome in health: establishment and resilience of microbiota over a lifetime. Environ Microbiol. 2016;18:2103-16.

8. Castellarin M, Warren RL, Freeman JD, Dreolini L, Krzywinski $\mathrm{M}$, Strauss J, et al. Fusobacterium nucleatum infection is prevalent in human colorectal carcinoma. Genome Res. 2012;22:299-306.

9. Raza MH, Gul K, Arshad A, Riaz N, Waheed U, Rauf A, et al. Microbiota in cancer development and treatment. J Cancer Res Clin Oncol. 2019;145:49-63.

10. Sivan A, Corrales L, Hubert N, Williams JB, Aquino-Michaels K, Earley ZM, et al. Commensal Bifidobacterium promotes antitumor immunity and facilitates anti-PD-L1 efficacy. Science. 2015;350:1084-9.

11. Schmidt TSB, Raes J, Bork P. The human gut microbiome: from association to modulation. Cell. 2018;172:1198-215.

12. Cani PD. Human gut microbiome: hopes, threats and promises. Gut. 2018;67:1716-25.

13. Vivarelli S, Salemi R, Candido S, Falzone L, Santagati M, Stefani $\mathrm{S}$, et al. Gut microbiota and cancer: from pathogenesis to therapy. Cancers (Basel). 2019;11:38.

14. Carding S, Verbeke K, Vipond DT, Corfe BM, Owen LJ. Dysbiosis of the gut microbiota in disease. Microb Ecol Health Dis. $2015 ; 26: 26191$.

15. Schumacher TN, Schreiber RD. Neoantigens in cancer immunotherapy. Science. 2015;348:69-74.

16. Hanahan D, Coussens LM. Accessories to the crime: functions of cells recruited to the tumor microenvironment. Cancer Cell. 2012;21:309-22.

17. Joyce JA, Fearon DT. T cell exclusion, immune privilege, and the tumor microenvironment. Science. 2015;348:74-80.

18. Guerra L, Guidi R, Frisan T. Do bacterial genotoxins contribute to chronic inflammation, genomic instability and tumor progression? FEBS J. 2011;278:4577-88.

19. Hekmatshoar Y, Rahbar Saadat Y, Hosseiniyan Khatibi SM, Ozkan T, Zununi Vahed F, Nariman-Saleh-Fam Z, et al. The impact of tumor and gut microbiotas on cancer therapy: beneficial or detrimental? Life Sci. 2019;233:116680.

20. Nougayrède JP, Homburg S, Taieb F, Boury M, Brzuszkiewicz E, Gottschalk G, et al. Escherichia coli induces DNA double-strand breaks in eukaryotic cells. Science. 2006;313:848-51.

21. Putze J, Hennequin C, Nougayrède JP, Zhang W, Homburg S, Karch H, et al. Genetic structure and distribution of the colibactin genomic island among members of the family Enterobacteriaceae. Infect Immun. 2009;77:4696-703.

22. Arthur JC, Gharaibeh RZ, Mühlbauer M, Perez-Chanona E, Uronis JM, McCafferty J, et al. Microbial genomic analysis 
reveals the essential role of inflammation in bacteria-induced colorectal cancer. Nat Commun. 2014;5:4724.

23. Arthur JC, Perez-Chanona E, Mühlbauer M, Tomkovich S, Uronis JM, Fan TJ, et al. Intestinal inflammation targets cancer-inducing activity of the microbiota. Science. 2012;338:120-3.

24. Goodwin AC, Destefano Shields CE, Wu S, Huso DL, Wu X, Murray-Stewart TR, et al. Polyamine catabolism contributes to enterotoxigenic Bacteroides fragilis-induced colon tumorigenesis. Proc Natl Acad Sci U S A. 2011;108:15354-9.

25. Clevers $H$, Nusse R. Wnt $/ \beta$-catenin signaling and disease. Cell. 2012;149:1192-205.

26. Nusse R, Clevers H. Wnt/ $\beta$-catenin signaling, disease, and emerging therapeutic modalities. Cell. 2017;169:985-99.

27. Loh KM, van Amerongen R, Nusse R. Generating cellular diversity and spatial form: Wnt signaling and the evolution of multicellular animals. Dev Cell. 2016;38:643-55.

28. Holstein TW. The evolution of the Wnt pathway. Cold Spring Harb Perspect Biol. 2012;4:a007922.

29. Kretzschmar K, Clevers $H$. Wnt $/ \beta$-catenin signaling in adult mammalian epithelial stem cells. Dev Biol. 2017;428:273-82.

30. Majidinia M, Aghazadeh J, Jahanban-Esfahlani R, Yousefi B. The roles of $\mathrm{Wnt} / \beta$-catenin pathway in tissue development and regenerative medicine. J Cell Physiol. 2018;233:5598-612.

31. Krausova M, Korinek V. Wnt signaling in adult intestinal stem cells and cancer. Cell Signal. 2014;26:570-9.

32. Lu R, Liu X, Wu S, Xia Y, Zhang YG, Petrof EO, et al. Consistent activation of the $\beta$-catenin pathway by Salmonella type-three secretion effector protein AvrA in chronically infected intestine. Am J Physiol Gastrointest Liver Physiol. 2012;303:G1113-25.

33. Panebianco C, Andriulli A, Pazienza V. Pharmacomicrobiomics: exploiting the drug-microbiota interactions in anticancer therapies. Microbiome. 2018;6:92.

34. Zitvogel L, Galluzzi L, Viaud S, Vétizou M, Daillère R, Merad M, et al. Cancer and the gut microbiota: an unexpected link. Sci Transl Med. 2015;7(271):271ps1.

35. Hooper LV, Littman DR, Macpherson AJ. Interactions between the microbiota and the immune system. Science. 2012;336:126873.

36. Liu Y, Baba Y, Ishimoto T, Iwatsuki M, Hiyoshi Y, Miyamoto Y, et al. Progress in characterizing the linkage between Fusobacterium nucleatum and gastrointestinal cancer. J Gastroenterol. 2019;54:33-41.

37. Panebianco C, Potenza A, Andriulli A, Pazienza V. Exploring the microbiota to better understand gastrointestinal cancers physiology. Clin Chem Lab Med. 2018;56(9):1400-12.

38. Rea D, Coppola G, Palma G, Barbieri A, Luciano A, Del Prete P, et al. Microbiota effects on cancer: from risks to therapies. Oncotarget. 2018;9:17915-27.

39. Wong SH, Kwong TNY, Wu CY, Yu J. Clinical applications of gut microbiota in cancer biology. Semin Cancer Biol. 2019;55: 28-36.

40. Panebianco C, Adamberg K, Jaagura M, Copetti M, Fontana A, Adamberg $\mathrm{S}$, et al. Influence of gemcitabine chemotherapy on the microbiota of pancreatic cancer xenografted mice. Cancer Chemother Pharmacol. 2018;81:773-82.

41. DiDonato JA, Mercurio F, Karin M. NF- $\mathrm{kB}$ and the link between inflammation and cancer. Immunol Rev. 2012;246:379-400.

42. Grivennikov SI, Wang K, Mucida D, Stewart CA, Schnabl B, Jauch D, et al. Adenoma-linked barrier defects and microbial products drive IL-23/IL-17-mediated tumour growth. Nature. 2012;491:254-8.

43. Schwabe RF, Jobin C. The microbiome and cancer. Nat Rev Cancer. 2013;13:800-12.

44. Elinav E, Nowarski R, Thaiss CA, Hu B, Jin C, Flavell RA. Inflammation-induced cancer: crosstalk between tumours, immune cells and microorganisms. Nat Rev Cancer. 2013;13: 759-71.

45. Grivennikov SI, Karin M. Inflammatory cytokines in cancer: tumour necrosis factor and interleukin 6 take the stage. Ann Rheum Dis. 2011;70:1104-8.

46. Grivennikov SI. IL-11: a prominent pro-tumorigenic member of the IL-6 family. Cancer Cell. 2013;24:145-7.

47. $\mathrm{Yu} \mathrm{H}$, Pardoll D, Jove R. STATs in cancer inflammation and immunity: a leading role for STAT3. Nat Rev Cancer. 2009;9: 798-809.

48. Li N, Grivennikov SI, Karin M. The unholy trinity: inflammation, cytokines, and STAT3 shape the cancer microenvironment. Cancer Cell. 2011;19:429-31.

49. Valenzano M, Bisio A, Grassi G. Helicobacter pylori and diabetes mellitus: a controversial relationship. Minerva Endocrinol. 2019;44:301-9.

50. Warren JR, Marshall B. Unidentified curved bacilli on gastric epithelium in active chronic gastritis. Lancet. 1983;1:1273-5.

51. Parsonnet J, Friedman GD, Vandersteen DP, Chang Y, Vogelman $\mathrm{JH}$, Orentreich N, et al. Helicobacter pylori infection and the risk of gastric carcinoma. N Engl J Med. 1991;325:1127-31.

52. Nomura A, Stemmermann GN, Chyou PH, Kato I, Perez-Perez GI, Blaser MJ. Helicobacter pylori infection and gastric carcinoma among Japanese Americans in Hawaii. N Engl J Med. 1991;325: 1132-6.

53. Forman D, Newell DG, Fullerton F, Yarnell JW, Stacey AR, Wald $\mathrm{N}$, et al. Association between infection with helicobacter pylori and risk of gastric cancer: evidence from a prospective investigation. BMJ. 1991;302:1302-5.

54. Correa P, Fox J, Fontham E, Ruiz B, Lin YP, Zavala D, et al. Helicobacter pylori and gastric carcinoma. Serum antibody prevalence in populations with contrasting cancer risks. Cancer. 1990;66:2569-74.

55. Sipponen P, Hyvarinen H. Role of helicobacter pylori in the pathogenesis of gastritis, peptic ulcer and gastric cancer. Scand J Gastroenterol Suppl. 1993;196:3-6.

56. Oberg K, Astrup L, Eriksson B, Falkmer SE, Falkmer UG, Gustafsen $\mathrm{J}$, et al. Guidelines for the management of gastroenteropancreatic neuroendocrine tumours (including bronchopulmonary and thymic neoplasms). Part II-specific NE tumour types. Acta Oncol. 2004;43:626-36.

57. Grozinsky-Glasberg S, Alexandraki KI, Angelousi A, Chatzellis E, Sougioultzis S, Kaltsas G. Gastric carcinoids. Endocrinol Metab Clin N Am. 2018;47:645-60.

58. Antonodimitrakis P, Tsolakis A, Welin S, Kozlovacki G, Oberg $\mathrm{K}$, Granberg D. Gastric carcinoid in a patient infected with helicobacter pylori: a new entity? World J Gastroenterol. 2011;17:3066-8

59. Takahashi S. Long-term helicobacter pylori infection and the development of atrophic gastritis and gastric cancer in Japan. J Gastroenterol. 2002;37:24-7.

60. Hirayama F, Takagi S, Iwao E, Yokoyama Y, Haga K, Hanada S. Development of poorly differentiated adenocarcinoma and carcinoid due to long-term helicobacter pylori colonization in Mongolian gerbils. J Gastroenterol. 1999;34:450-4.

61. Sato Y, Iwafuchi M, Ueki J, Yoshimura A, Mochizuki T, Motoyama H, et al. Gastric carcinoid tumors without autoimmune gastritis in Japan: a relationship with helicobacter pylori infection. Dig Dis Sci. 2002;47:579-85.

62. Kagawa J, Honda S, Kodama M, Sato R, Murakami K, Fujioka T. Enterocromaffin-like cell tumor induced by helicobacter pylori infection in Mongolian gerbils. Helicobacter. 2002;7:390-7.

63. Cao L, Mizoshita T, Tsukamoto T, Takenaka Y, Toyoda T, Cao $\mathrm{X}$, et al. Development of carcinoid tumors of the glandular stomach and effects of eradication in helicobacter pylori-infected Mongolian gerbils. Asian Pac J Cancer Prev. 2008;9:25-30. 
64. Murphy G, Dawsey SM, Engels EA, Ricker W, Parsons R, Etemadi A, et al. Cancer risk after pernicious anemia in the US elderly population. Clin Gastroenterol Hepatol. 2015;13:2282-9.

65. Solcia E, Rindi G, Fiocca R, Villani L, Buffa R, Ambrosiani L, et al. Distinct patterns of chronic gastritis associated with carcinoid and cancer and their role in tumorigenesis. Yale J Biol Med. 1992;65:793-804.

66. Karnes WE Jr, Samloff IM, Siurala M, Kekki M, Sipponen P, Kim $\mathrm{SW}$, et al. Positive serum antibody and negative tissue staining for helicobacter pylori in subjects with atrophic body gastritis. Gastroenterology. 1991;101:167-74.

67. Ananthamurthy A, Correa M, Patil M. Type 1 gastric carcinoid in the indian population and its association with multifocal gastric atrophy. Euroasian J Hepatogastroenterol. 2016;6:106-10.

68. Modlin M, Tang LH. The gastric enterochromaffin-like cell: an enigmatic cellular lesion. Gastroenterology. 1996;111:783-810.

69. Sue S, Shibata W, Maeda S. Helicobacter pylori-induced signaling pathways contribute to intestinal metaplasia and gastric carcinogenesis. Biomed Res Int. 2015;2015:737621.

70. Kidd M, Miu K, Tang LH, Perez-Perez GI, Blaser MJ, Sandor A, et al. Helicobacter pylori lipopolysaccharide stimulates histamine release and DNA synthesis in rat enterochromaffin-like cells. Gastroenterology. 1997;113:1110-7.

71. Modlin M, Kidd M, Miu K, Tang LH. The effect of Helicobacter pylori on enterochromaffin-like (ECL) cell function. Helicobacter pylori pp 176-187.

72. Kinoshita Y, Ishihara S, Kadowaki Y, Fukui H, Chiba T. Reg protein is a unique growth factor of gastric mucosal cells. J Gastroenterol. 2004;39:507-13.

73. Chang WL, Yeh YC, Sheu BS. The impacts of $\mathrm{H}$ pylori virulence factors on the development of gastroduodenal diseases. J Biomed Sci. 2018;25:68.

74. Bowen KA, Silva SR, Johnson JN, Doan HQ, Jackson LN, Gulhati P, et al. An analysis of trends and growth factor receptor expression of GI carcinoid tumors. Gastrointest Surg. 2009;13: 1773-80.

75. Besig S, Voland P, Baur DM, Perren A, Prinz C. Vascular endothelial growth factors, angiogenesis, and survival in human ileal enterochromaffin cell carcinoids. Neuroendocrinology. 2009;90: 402-15.

76. Shah T, Hochhauser D, Frow R, Quaglia A, Dhillon AP, Caplin ME. Epidermal growth factor receptor expression and activation in neuroendocrine tumours. J Neuroendocrinol. 2006;18:355-60.

77. Azzoni C, Bottarelli L, Cecchini S, Lagrasta C, Pizzi S, D'Adda T, et al. Involvement of HER-2/neu and metastasis-related proteins in the development of ileal neuroendocrine tumors. Virchows Arch. 2011;458:525-36.

78. Grillo F, Florio T, Ferraù F, Kara E, Fanciulli G, Faggiano A, et al. Emerging multitarget tyrosine kinase inhibitors in the treatment of neuroendocrine neoplasms. Endocr Relat Cancer. 2018;25:R45366.

79. de Jesus SM, de Moraes JA, Da Silva VN, Helal-Neto E, Uberti AF, Scopel-Guerra A, et al. Helicobacter pylori urease induces pro-inflammatory effects and differentiation of human endothelial cells: cellular and molecular mechanism. Helicobacter. 2019 Jun;24:e12573.

80. Keates S, Keates AC, Katchar K, Peek RM Jr, Kelly CP. Helicobacter pylori induces up-regulation of the epidermal growth factor receptor in AGS gastric epithelial cells. J Infect Dis. 2007;196:95-103.

81. Gunawardhana N, Jang S, Choi YH, Hong YA, Jeon YE, Kim A, et al. Helicobacter pylori-induced HB-EGF upregulates gastrin expression via the EGF receptor, C-Raf, Mek1, and Erk2 in the MAPK pathway. Front Cell Infect Microbiol. 2018;7:541.
82. Kwok T, Zabler D, Urman S, Rohde M, Hartig R, Wessler S, et al. Helicobacter exploits integrin for type IV secretion and kinase activation. Nature. 2007;449:862-6.

83. Tegtmeyer N, Zabler D, Schmidt D, Hartig R, Brandt S, Backert S. Importance of EGF receptor, HER2/Neu and Erk1/2 kinase signalling for host cell elongation and scattering induced by the helicobacter pylori CagA protein: antagonistic effects of the vacuolating cytotoxin VacA. Cell Microbiol. 2009;11:488-505.

84. Davies H, Bignell GR, Cox C, Stephens P, Edkins S, Clegg S, et al. Mutations of the BRAF gene in human cancer. Nature. 2002;417:949-54.

85. Jiao Y, Shi C, Edil BH, de Wilde RF, Klimstra DS, Maitra A, et al. DAXX/ATRX, MEN1, and mTOR pathway genes are frequently altered in pancreatic neuroendocrine tumours. Science. 2011;331: 1199-203.

86. Gilbert JA, Adhikari LJ, Lloyd RV, Halfdanarson TR, Muders MH, Ames MM. Molecular markers for novel therapeutic strategies in pancreatic endocrine tumours. Pancreas. 2013;42:411-21.

87. Astsaturov IA, Cohen SJ, Engstrom PF, Gatalica Z, Bender RP, Basu GD, et al. Profiling of a global cohort of 1250 neuroendocrine tumours to identify multiple potential drug targets. J Clin Oncol. 2014;32:214-4. https://doi.org/10.1200/jco.2014.32.3_ suppl.214.

88. Tannapfel A, Vomschloss S, Karhoff D, Markwarth A, Hengge UR, Wittekind C, et al. BRAF gene mutations are rare events in gastroenteropancreatic neuroendocrine tumors. Am J Clin Pathol. 2005; 123:256-60.

89. Karhoff D, Sauer S, Schrader J, Arnold R, Fendrich V, Bartsch $\mathrm{DK}$, et al. Rap1/B-Raf signaling is activated in neuroendocrine tumors of the digestive tract and Raf kinase inhibition constitutes a putative therapeutic target. Neuroendocrinology. 2007;851:4553.

90. Sippel RS, Carpenter JE, Kunnimalaiyaan M, Lagerholm S, Chen H. Raf-1 activation suppresses neuroendocrine marker and hormone levels in human gastrointestinal carcinoid cells. Am J Physiol Gastrointest Liver Physiol. 2003;285:G245-54.

91. Ning L, Chen H, Kunnimalaiyaan M. Focal adhesion kinase, a downstream mediator of Raf-1 signaling, suppresses cellular adhesion, migration, and neuroendocrine markers in $\mathrm{BON}$ carcinoid cells. Mol Cancer Res. 2010;8:775-82.

92. Rozengurt E, Walsh JH. Gastrin, CCK, signaling, and cancer. Annu Rev Physiol. 2001;63:49-76.

93. Chalmers CJ, Gilley R, March HN, Balmanno K, Cook SJ. The duration of ERK $1 / 2$ activity determines the activation of c-Fos and Fra- 1 and the composition and quantitative transcriptional output of AP-1. Cell Signal. 2007;19:695-704.

94. Treinies I, Paterson HF, Hooper S, Wilson R, Marshall CJ. Activated MEK stimulates expression of AP-1 components independently of phosphatidylinositol 3-kinase (PI3-kinase) but requires a PI3-kinase signal to stimulate DNA synthesis. Mol Cell Biol. 1999;19:321-9.

95. Kinoshita Y, Nakata H, Kishi K, Kawanami C, Sawada M, Chiba T. Comparison of the signal transduction pathways activated by gastrin in enterochromaffin-like and parietal cells. Gastroenterology. 1998;115:93-100.

96. Naumann M, Crabtree JE. Helicobacter pylori-induced epithelial cell signalling in gastric carcinogenesis. Trends Microbiol. 2004;12:29-36.

97. Hisatsune J, Nakayama M, Isomoto H, Kurazono H, Mukaida N, Mukhopadhyay AK, et al. Molecular characterization of helicobacter pylori VacA induction of IL-8 in U937 cells reveals a prominent role for $\mathrm{p} 38 \mathrm{MAPK}$ in activating transcription Factor2, cAMP response element binding protein, and NF- $\mathrm{KB}$ activation. J Immunol. 2008;180:5017-27.

98. Nakayama M, Kimura M, Wada A, Yahiro K, Ogushi K, Niidome T, et al. Helicobacter pylori VacA activates the p38/activating 
transcription factor 2-mediated signal pathway in AZ-521 cells. J Biol Chem. 2004;279:7024-8.

99. Lee IO, Kim JH, Choi YJ, Pillinger MH, Kim SY, Blaser MJ, et al. Helicobacter pylori CagA phosphorylation status determines the gp130-activated SHP2/ERK and JAK/STAT signal transduction pathways in gastric epithelial cells. Biol Chem. 2010;285:1604250 .

100. Keates S, Keates AC, Warny M, Peek RM Jr, Murray PG, Kelly CP. Differential activation of mitogen-activated protein kinases in AGS gastric epithelial cells by cagand cag helicobacter pylori. J Immunol. 1999;163:5552-9.

101. Berardi R, Morgese F, Torniai M, Savini A, Partelli S, Rinaldi S, et al. Medical treatment for gastro-entero-pancreatic neuroendocrine tumours. World J Gastrointest Oncol. 2016;8:389-401.

102. Svejda B, Kidd M, Kazberouk A, Lawrence B, Pfragner R, Modlin IM. Limitations in small intestinal neuroendocrine tumor therapy by mTor kinase inhibition reflect growth factor-mediated PI3K feedback loop activation via ERK1/2 and AKT. Cancer. 2011;117:4141-54.

103. Yang Z, Xie C, Xu W, Liu G, Cao X, Li W, et al. Phosphorylation and inactivation of PTEN at residues Ser380/Thr382/383 induced by helicobacter pylori promotes gastric epithelial cell survival through PI3K/Akt pathway. Oncotarget. 2015;6:31916-26.

104. Tabassam FH, Graham DY, Yamaoka Y. Helicobacter pyloriassociated regulation of forkhead transcription factors FoxO1/3a in human gastric cells. Helicobacter. 2012;17:193-202.

105. Valenzuela-Valderrama M, Cerda-Opazo P, Backert S, González MF, Carrasco-Véliz N, Jorquera-Cordero C, et al. The helicobacter pylori urease virulence factor is required for the induction of hypoxia-induced factor- $1 \alpha$ in gastric cells. Cancers. 2019;11:799.

106. Wang H, Chen Y, Fernandez-Del Castillo C, Yilmaz O, Deshpande V. Heterogeneity in signalling pathways of gastroenteropancreatic neuroendocrine tumors: a critical look at notch signaling pathway. Mod Pathol. 2013;26:139-47.

107. Liu T, He W, Li Y. Helicobacter pylori infection of gastric epithelial cells affects NOTCH pathway in vitro. Dig Dis Sci. 2016;61: 2516-21.

108. Kim JT, Li J, Jang ER, Gulhati P, Rychahou PG, Napier DL, et al. Deregulation of $\mathrm{Wnt} / \beta$-catenin signaling through genetic or epigenetic alterations in human neuroendocrine tumors. Carcinogenesis. 2013;34:953-61.

109. Su MC, Wang CC, Chen CC, Hu RH, Wang TH, Kao HL, et al. Nuclear translocation of beta-catenin protein but absence of betacatenin and APC mutation in gastrointestinal carcinoid tumor. Ann Surg Oncol. 2006;13:1604-9.

110. Fujimori M, Ikeda S, Shimizu Y, Okajima M, Asahara T. Accumulation of beta-catenin protein and mutations in exon 3 of beta-catenin gene in gastrointestinal carcinoid tumor. Cancer Res. 2001;61:6656-9.

111. Bottarelli L, Azzoni C, Pizzi S, D'Adda T, Silini EM, Bordi C, et al. Adenomatous polyposis coli gene involvement in ileal enterochromaffin cell neuroendocrine neoplasms. Hum Pathol. 2013;44:2736-42.

112. Franco AT, Israel DA, Washington MK, Krishna U, Fox JG, Rogers $\mathrm{AB}$, et al. Activation of beta-catenin by carcinogenic helicobacter pylori. Proc Natl Acad Sci U S A. 2005;102: 10646-51.

113. Nagy TA, Wroblewski LE, Wang D, Piazuelo MB, Delgado A, Romero-Gallo J, et al. $\beta$-Catenin and p120 mediate PPAR $\delta$ dependent proliferation induced by Helicobacter pylori in human and rodent epithelia. Gastroenterology. 2011;141:553-64.

114. Ito K, Chuang LS, Ito T, Chang TL, Fukamachi H, Salto-Tellez $\mathrm{M}$, et al. Loss of Runx3 is a key event in inducing precancerous state of the stomach. Gastroenterology. 2011;140:1536-46e8.
115. Nakayama M, Hisatsune J, Yamasaki E, Isomoto H, Kurazono H, Hatakeyama M, et al. Helicobacter pylori VacA-induced inhibition of GSK3 through the PI3K/Akt signaling pathway. J Biol Chem. 2009;284:1612-9.

116. Schumacher MA, Donnelly JM, Engevik AC, Xiao C, Yang L, Kenny S, et al. Gastric Sonic Hedgehog acts as a macrophage chemoattractant during the immune response to Helicobacter pylori. Gastroenterology. 2012;142:1150-59.e6.

117. Liu N, Zhou N, Chai N, Liu X, Jiang H, Wu Q, et al. Helicobacter pylori promotes angiogenesis depending on Wnt/beta-catenin-mediated vascular endothelial growth factor via the cyclooxygenase2 pathway in gastric cancer. BMC Cancer. 2016;16:321.

118. Papageorgis $\mathrm{P}$. TGFbeta signaling in tumor initiation, epithelial to mesenchymal transition and metastasis. J.Oncol. 2015;2015: 587193.

119. Samanta D, Datta PK. Alterations in the Smad pathway in human cancers. Front Biosci (Landmark Ed). 2012;17:1281-93.

120. Akhurst RJ, Hata A. Targeting the TGFbeta signalling pathway in disease. Nat Rev Drug Discov. 2012;11:790-811.

121. $\mathrm{Xu} \mathrm{X,} \mathrm{Zhu} \mathrm{L.} \mathrm{MiR-124} \mathrm{promotes} \mathrm{proliferation} \mathrm{and} \mathrm{differentiation}$ of osteoblasts via BMP/TGF- $\beta$ signaling pathway. Minerva Endocrinol. 2019.

122. Gilbert JA, Adhikari LJ, Lloyd RV, Rubin J, Haluska P, Carboni $\mathrm{JM}$, et al. Molecular markers for novel therapies in neuroendocrine (carcinoid) tumors. Endocr Relat Cancer. 2010;17:623-36.

123. Roland CL, Starker LF, Kang Y, Chatterjee D, Estrella J, Rashid A, et al. Surgery. Loss of DPC4/SMAD4 expression in primary gastrointestinal neuroendocrine tumors is associated with cancerrelated death after resection. 2017;161:753-9.

124. Banck MS, Kanwar R, Kulkarni AA, Boora GK, Metge F, Kipp $\mathrm{BR}$, et al. The genomic landscape of small intestine neuroendocrine tumors. J Clin Invest. 2013;123:2502-8.

125. Kidd M, Modlin IM, Pfragner R, Eick GN, Champaneria MC, Chan AK, et al. Small bowel carcinoid (enterochromaffin cell) neoplasia exhibits transforming growth factor-b1-mediated regulatory abnormalities including up-regulation of C-Myc and MTA1. Cancer. 2007;109:2420-31.

126. Rahimian G, Sanei MH, Shirzad H, Azadegan-Dehkordi F, Taghikhani A, et al. Virulence factors of helicobacter pylori vacA increase markedly gastric mucosal TGF- $\beta 1$ mRNA expression in gastritis patients. Microb Pathog. 2014;67-68:1-7.

127. Inoue K, Fry EA, Frazier DP. Transcription factors that interact with p53 and Mdm2. Int J Cancer. 2016;138:1577-85.

128. Zhao Y, Aguilar A, Bernard D, Wang S. Small-molecule inhibitors of the MDM2-p53 protein-protein interaction (MDM2 inhibitors) in clinical trials for cancer treatment. J Med Chem. 2015;58: 1038-52.

129. Brazina J, Svadlenka J, Macurek L, Andera L, Hodny Z, Bartek J, et al. DNA damage-induced regulatory interplay between DAXX, p53, ATM kinase and Wip1 phosphatase. Cell Cycle. 2015;14: 375-87.

130. Makuuchi R, Terashima M, Kusuhara M, Nakajima T, Serizawa $\mathrm{M}$, Hatakeyama $\mathrm{K}$, et al. Comprehensive analysis of gene mutation and expression profiles in neuroendocrine carcinomas of the stomach. Biomed Res. 2017;38:19-27.

131. Vijayvergia N, Boland PM, Handorf E, Gustafson KS, Gong Y, Cooper HS, et al. Molecular profiling of neuroendocrine malignancies to identify prognostic and therapeutic markers: a Fox Chase Cancer Center pilot study. Br J Cancer. 2016;115:564-70.

132. Hu W, Feng Z, Modica I, Klimstra DS, Song L, Allen PJ, et al. Gene amplifications in well-differentiated pancreatic neuroendocrine tumors inactivate the p53 pathway. Genes Cancer. 2010;1: $360-8$.

133. Shin JU, Lee CH, Lee KT, Lee JK, Lee KH, Kim KM, et al. Prognostic significance of ATM and cyclin B1 in pancreatic neuroendocrine tumor. Tumour Biol. 2012;33:1645-51. 
134. Lee J, Sung CO, Lee EJ, Do IG, Kim HC, Yoon SH, et al. Metastasis of neuroendocrine tumors are characterized by increased cell proliferation and reduced expression of the ATM gene. PLoS One. 2012:7-e34456.

135. Luque EA, Tang LH, Bortecen KH, Kidd M, Miu K, Efstathiou $\mathrm{JA}$, et al. Gastrin-regulated expression of $\mathrm{p} 53$ in transformed enterochromaffin-like cells in the african rodent mastomys. J Clin Gastroenterol. 1998;27(Suppl 1):S116-24.

136. Wei J, Nagy TA, Vilgelm A, Zaika E, Ogden SR, Romero-Gallo J, et al. Regulation of $\mathrm{p} 53$ tumor suppressor by helicobacter pylori in gastric epithelial cells. Gastroenterology. 2010;139:1333-43.

137. Toller IM, Neelsen KJ, Steger M, Hartung ML, Hottiger MO, Stucki M, et al. Carcinogenic bacterial pathogen helicobacter pylori triggers DNA double-strand breaks and a DNA damage response in its host cells. Proc Natl Acad Sci U S A. 2011;108: 14944-9.

138. Casimiro MC, Crosariol M, Loro E, Li Z, Pestell RG. Cyclins and cell cycle control in cancer and disease. Genes Cancer. 2012;3: 649-57.

139. Cicenas J, Valius M. The CDK inhibitors in cancer research and therapy. J Cancer Res Clin Oncol. 2011;137:1409-18.

140. Cicenas J, Kalyan K, Sorokinas A, Jatulyte A, Valiunas D, Kaupinis A, et al. Highlights of the latest advances in research on CDK inhibitors. Cancers (Basel). 2014;6:2224-42.

141. Malumbres M. Perez de Castro I. Aurora kinase a inhibitors: promising agents in antitumoural therapy. Expert Opin Ther Targets. 2014;18:1377-93.

142. Law ME, Corsino PE, Narayan S, Law BK. Cyclin-dependent kinase inhibitors as anticancer therapeutics. Mol Pharmacol. 2015;88:846-52.

143. Malinkova V, Vylicil J, Krystof V. Cyclin-dependent kinase inhibitors for cancer therapy: a patent review (2009-2014). Expert Opin Ther Pat. 2015;25:953-70.

144. Tang LH, Contractor T, Clausen R, Klimstra DS, Du YC, Allen PJ, et al. Attenuation of the retinoblastoma pathway in pancreatic neuroendocrine tumours because of increased cdk4/cdk6. Clin Cancer Res. 2012;18:4612-20.

145. Francis JM, Kiezun A, Ramos AH, Serra S, Pedamallu CS, Qian $\mathrm{ZR}$, et al. Somatic mutation of CDKN1B in small intestine neuroendocrine tumors. Nat Genet. 2013;45:1483-6.

146. Karpathakis A, Dibra H, Pipinikas C, Feber A, Morris T, Francis J, et al. Prognostic impact of novel molecular subtypes of small intestinal neuroendocrine tumour. Clin Cancer Res. 2016;22: $250-8$.

147. Grabowski P, Schrader J, Wagner J, Horsch D, Arnold R, Arnold $\mathrm{CN}$, et al. Loss of nuclear $\mathrm{p} 27$ expression and its prognostic role in relation to cyclin $\mathrm{E}$ and p53 mutation in gastroenteropancreatic neuroendocrine tumours. Clin Cancer Res. 2008;14:7378-84. https://doi.org/10.1158/1078-0432.CCR-08-0698.

148. Yachida S, Vakiani E, White CM, Zhong Y, Saunders T, Morgan $\mathrm{R}$, et al. Small cell and large cell neuroendocrine carcinomas of the pancreas are genetically similar and distinct from welldifferentiated pancreatic neuroendocrine tumors. Am J Surg Pathol. 2012;36:173-84.

149. Zhang T, Tang L, Kidd M, Lauffer J, Modlin I. Gastric enterochromaffin-like (ECL) transformation is associated with increased expression of the G1 cell cycle regulators cyclin D1 and cdk4. Gastroenterology. 1998;114:G2932.

150. Kidd M, Hinoue T, Eick G, Lye KD, Mane SM, Wen Y, et al. Global expression analysis of ECL cells in Mastomys natalensis gastric mucosa identifies alterations in the AP-1 pathway induced by gastrin-mediated transformation. Physiol Genomics. 2004;20: 131-42.

151. Hönig A, Witte F, Mirecka J, Binder C, Schauer A. Helicobacter pylori-induced hyperproliferation: relevance for gastric cancer development in connection with mutagenic factors. Anticancer Res. 2000;20:1641-8.

152. Suzuki N, Wakasugi M, Nakaya S, Okada K, Mochida R, Sato M, et al. Production and application of new monoclonal antibodies specific for a fecal helicobacter pylori antigen. Clin Diagn Lab Immunol. 2002;9:75-8.

153. Byun SW, Chang YJ, Chung IS, Moss SF, Kim SS. Helicobacter pylori decreases $\mathrm{p} 27$ expression through the delta opioid receptormediated inhibition of histone acetylation within the $\mathrm{p} 27$ promoter. Cancer Lett. 2012;326:96-104.

154. Bahnassy AA, Helal TE, El-Ghazawy IM, Samaan GF, Galal ElDin MM, et al. The role of E-cadherin and Runx3 in helicobacter pylori - associated gastric carcinoma is achieved through regulating P21waf and P27 expression. Cancer Gene Ther. 2018;228229:64-72.

155. Eguchi H, Carpentier S, Kim SS, Moss SF. P27kip1 regulates the apoptotic response of gastric epithelial cells to helicobacter pylori. Gut. 2004;53:797-804.

156. La Rosa S, Rigoli E, Uccella S, Chiaravalli AM, Capella C. CDX2 as a marker of intestinal EC-cells and related well-differentiated endocrine tumors. Virchows Arch. 2004;445:248-54.

157. Srivastava A, Hornick JL. Immunohistochemical staining for CDX-2, PDX-1, NESP-55 and TTF-1 can help distinguish gastrointestinal carcinoid tumors from pancreatic endocrine and pulmonary carcinoid tumors. Am J Surg Pathol. 2009;33:626-32.

158. Herman Mahečić D, Cigrovski Berković M, Zjačić-Rotkvić V, Čačev T, Kapitanović S, Ulamec M. Inflammation-related cytokines and their roles in gastroenteropancreatic neuroendocrine neoplasms. Bosn J Basic Med Sci. 2020.

159. Kinoshita H, Hirata $Y$, Nakagawa H, Sakamoto K, Hayakawa $Y$, Takahashi R, et al. Interleukin-6 mediates epithelial-stromal interactions and promotes gastric tumorigenesis. PLoS One. 2013;8: e60914.

160. Hatakeyama M. Helicobacter pylori CagA and gastric cancer: a paradigm for hit-and-run carcinogenesis. Cell Host Microbe. 2014;15:306-16

161. Wang TC, Goldenring JR. Inflammation intersection: gp130 balances gut irritation and stomach cancer. Nat Med. 2002;8:1080-2.

162. Tebbutt NC, Giraud AS, Inglese M, Jenkins B, Waring P, Clay FJ, et al. Reciprocal regulation of gastrointestinal homeostasis by SHP2 and STAT-mediated trefoil gene activation in gp130 mutant mice. Nat Med. 2002;8:1089-97.

163. Satoh K, Mutoh H, Eda A, Yanaka I, Osawa H, Honda S, et al. Aberrant expression of CDX2 in the gastric mucosa with and without intestinal metaplasia: effect of eradication of helicobacter pylori. Helicobacter. 2002;7:192-8.

164. Kim HS, Lee HS, Kim WH. Clinical significance of protein expression of cyclooxygenase- 2 and somatostatin receptors in gastroenteropancreatic neuroendocrine tumors. Cancer Res Treat. 2011;43:181-8.

165. Liu B, Qu L, Yan S. Cyclooxygenase-2 promotes tumor growth and suppresses tumor immunity. Cancer Cell Int. 2015;15:106.

166. Fu S, Ramanujam KS, Wong A, Fantry GT, Drachenberg CB, James SP, et al. Increased expression and cellular localization of inducible nitric oxide synthase and cyclooxygenase 2 in helicobacter pylori gastritis. Gastroenterology. 1999;116:1319 29.

167. Pero R, Peluso S, Angrisano T, Tuccillo C, Sacchetti S, Keller S, et al. Chromatin and DNA methylation dynamics of helicobacter pylori-induced COX-2 activation. Int J Med Microbiol. 2011;301: $140-9$.

168. Zhang H, Ding C, Suo Z, Kang Y. Effect of helicobacter pylori on cyclooxygenase- 2 and inducible nitric oxide synthase in patients with gastric precancerous lesions and its clinical significance. Exp Ther Med. 2015;9:2364-8. 
169. Bojesen RD, Riis LB, Hogdall E, Nielsen OH, Jess T. Inflammatory bowel disease and small bowel cancer risk, clinical characteristics, and histopathology: a population-based study. Clin Gastroenterol Hepatol. 2017;15:1900-7.

170. Algaba A, Guerra I, Castano A, de la Poza G, Castellano VM, Lopez M, et al. Risk of cancer, with special reference to extraintestinal malignancies, in patients with inflammatory bowel disease. World J Gastroenterol. 2013;19:9359-65.

171. Lal P, Saleh MA, Khoudari G, Gad MM, Mansoor E, Isenberg G, et al. Epidemiology of large bowel carcinoid tumors in the USA: a population-based national study. Dig Dis Sci. 2020;65:269-75.

172. Sciola V, Massironi S, Conte D, Caprioli F, Ferrero S, Ciafardini $\mathrm{C}$, et al. Plasma chromogranin a in patients with inflammatory bowel disease. Inflamm Bowel Dis. 2009;15:867-71.

173. Derikx LA, Vierdag WM, Kievit W, Bosch S, Hoentjen F, Nagtegaal ID. Is the prevalence of colonic neuroendocrine tumors increased in patients with inflammatory bowel disease? Int J Cancer. 2016;139:535-42.

174. Praticò C, Rizzello F, Fornarini GS, Calafiore A, Calabrese C, Campieri M, et al. Four cases of carcinoid tumour in Crohn's disease: coincidence or correlation? Int J Color Dis. 2013;28: 1743-5.

175. Wong M, Larson BK, Dhall D. Neuroendocrine proliferations in inflammatory bowel disease: differentiating neuroendocrine tumours from neuroendocrine cell micronests. Histopathology. 2019;74:415-23.

176. Prosberg M, Bendtsen F, Vind I, Petersen AM, Gluud LL. The association between the gut microbiota and the inflammatory bowel disease activity: a systematic review and meta-analysis. Scand J Gastroenterol. 2016;51:1407-15.

177. Jostins L, Ripke S, Weersma RK, Duerr RH, McGovern DP, Hui $\mathrm{KY}$, et al. Host-microbe interactions have shaped the genetic architecture of inflammatory bowel disease. Nature. 2012;491:119 24.

178. Frank DN, St Amand AL, Feldman RA, Boedeker EC, Harpaz N, Pace NR. Molecular-phylogenetic characterization of microbial community imbalances in human inflammatory bowel diseases. Proc Natl Acad Sci U S A. 2007;104:13780-5.

179. Nell S, Suerbaum S, Josenhans C. The impact of the microbiota on the pathogenesis of IBD: lessons from mouse infection models. Nat Rev Microbiol. 2010;8:564-77.

180. Ni J, Wu JD, Albenberg L, Tomov VT. Gut microbiota and IBD: causation or correlation? Nat Rev Gastroenterol Hepatol. 2017;14: $573-84$.
181. Machiels K, Joossens M, Sabino J, De Preter V, Arijs I, Eeckhaut $\mathrm{V}$, et al. A decrease of the butyrate-producing species Roseburia hominis and Faecalibacterium prausnitzii defines dysbiosis in patients with ulcerative colitis. Gut. 2014;63:1275-83.

182. Manichanh C, Rigottier-Gois L, Bonnaud E, Gloux K, Pelletier E, et al. Reduced diversity of faecal microbiota in Crohn's disease revealed by a metagenomic approach. Gut. 2006;55:205-11.

183. Sokol H, Pigneur B, Watterlot L, Lakhdari O, BermúdezHumarán LG, Gratadoux JJ, et al. Faecalibacterium prausnitzii is an anti-inflammatory commensal bacterium identified by gut microbiota analysis of Crohn disease patients. Proc Natl Acad Sci U S A. 2008;105:16731-6.

184. Döerffel Y, Pavel M, Loening-Baucke V, Swidsinski A. Common biostructure of the fecal flora in celiac disease, Crohn's disease, and carcinoid tumors. Inflamm Bowel Dis. 2008;14:1613-4.

185. Varela E, Manichanh C, Gallart M, Torrejón A, Borruel N, Casellas F, et al. Colonization by Faecabalibacterium prausnitzii and maintenance of clinical remission in patients with ulcerative colitis. Aliment Pharmacol Ther. 2013;38:151-61.

186. Ferreira-Halder CV, Faria AVS, Andrade SS. Action and function of Faecalibacterium prausnitzii in health and disease. Best Pract Res Clin Gastroenterol. 2017;31:643-8.

187. Ma J, Sun L, Liu Y, Ren H, Shen Y, Bi F, et al. Alter between gut bacteria and blood metabolites and the anti-tumor effects of Faecalibacterium prausnitzii in breast cancer. BMC Microbiol. 2020;20:82.

188. Chaput N, Lepage P, Coutzac C, Soularue E, Le Roux K, Monot $\mathrm{C}$, et al. Baseline gut microbiota predicts clinical response and colitis in metastatic melanoma patients treated with ipilimumab. Ann Oncol. 2017;28:1368-79.

189. Zuo T, Ng SC. The gut microbiota in the pathogenesis and therapeutics of inflammatory bowel disease. Front Microbiol. 2018;9: 2247.

190. Sokol H, Leducq V, Aschard H, Pham HP, Jegou S, Landman C, et al. Fungal microbiota dysbiosis in IBD. Gut. 2017;66:1039-48.

191. Tamagno G, Bennett A, Ivanovski I. Lights and darks of neuroendocrine tumors of the appendix. Minerva Endocrinol. 2020 Jul 23. Online ahead of print. https://doi.org/10.23736/S03911977.20.03206-X.

Publisher's note Springer Nature remains neutral with regard to jurisdictional claims in published maps and institutional affiliations. 